\title{
Mental Health in Health Students during Coronavirus Disease-19: Systematic Review
}

\author{
Agus Purnama ${ }^{1 *}$, Susaldi ${ }^{1}$, Halma Zahro Mukhlida ${ }^{1}$, Hilma Hasro Maulida ${ }^{1}$, Nyimas Heny Purwati ${ }^{2}$ \\ ${ }^{1}$ Departement of Nursing, Sekolah Tinggi IImu Kesehatan Indonesia Maju, Jakarta, Indonesia; ${ }^{2}$ Departement of Nursing \\ Universitas Muhammadiyah Jakarta, Indonesia
}

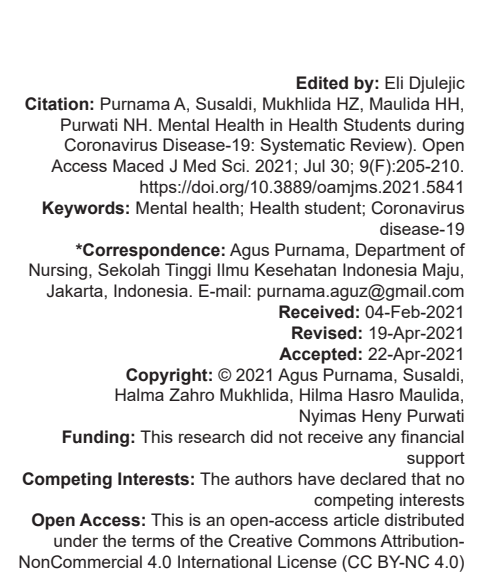

\section{Introduction}

Coronavirus disease (COVID)-19 is a type of disease that attacks humans caused by a new virus called severe acute respiratory syndrome coronavirus-2 [1] where the first case of COVID-19 affecting humans occurred in Wuhan China on December 31, 2019 [2], [3]. The results of studies conducted reported that COVID19 has an impact on a person's mental health conditions, which include depression, anxiety, and stress [4]. The anxiety that occurs does not only have an impact on society in general but also what is of great concern is anxiety for health workers who treat patients with a diagnosis of COVID-19 in the hospital, one of which is a nurse who reports high levels of anxiety [5], [6]. Besides that, those affected by the COVID-19 outbreak are students who are carrying out education where the results show a fairly high rate of depression that occurs even though there is no significant difference in the level of depression between female students and male students [7]. In addition to the depression rate, another problem that was reported was anxiety that occurred in some students who were carrying out distance learning during this pandemic condition, one of the students who were seriously affected was health students, be it medicine, nursing, and other health students, they considered the COVID-19 outbreak. -19 This is a serious condition that can have serious consequences if not treated promptly [8]. Nursing students assessed the perceived anxiety due to fear of lack of personal protective equipment and fear of infection when faced with unpredictable environmental conditions [9]. Some concerns even so that health students have good knowledge and sufficient coping mechanisms in responding to the COVID-19 pandemic that has hit almost all countries around the world [10]. Given the importance of discussing the effects of the COVID-19 pandemic that can be experienced by students, especially health students who are the backbone of future health, the aim of this study is to discuss various topics related to psychological pressure on health students during the COVID-19 pandemic.

\section{Methods}

Design in this study is a literature study using the Preferred Reporting Items for Systematic Reviews and Meta-Analysis guide as a guide to getting articles 
as shown in Figure 1 to be reviewed in depth. This study uses the PIO format (Population, Intervention/ Exposure, Outcome). P: Health Student, I: COVID19, O: Mental Health. The database used in this study consisted of three databases, namely Springer, ScienceDirect, and ProQuest. The keywords in this study were Mental Health AND Student Health AND COVID-19. The inclusion criteria in this study were to focus on the mental health of health students during the pandemic, studies using quantitative design methods, English articles, the time span used in this study was between January 2020 and December 2020. The exclusion criteria in this study research with the qualitative design, mental health problems in nonhealth students, epidemiological research, and a letter to the editor were excluded from the study. Research that meets the criteria is shown in a systematic review table. The contents of the table consist of the author's name, year, country, the design used, population and sample, type of mental health disorder experienced, instruments used, and conclusions.

\section{Results}

Total of all searches from the three databases was obtained by the number of 677 Springer articles, 556 Science directed articles, and 1348 ProQuest articles. Eleven were deleted because of duplicates, 446 full-text reviews, and eight articles that match the inclusion and exclusion criteria. Table 1 shows the literature review on mental health in health students in the midst of the COVID-19 pandemic. Eight articles were reviewed and found that most of the health students reported mental health problems such as anxiety, depression, stress,

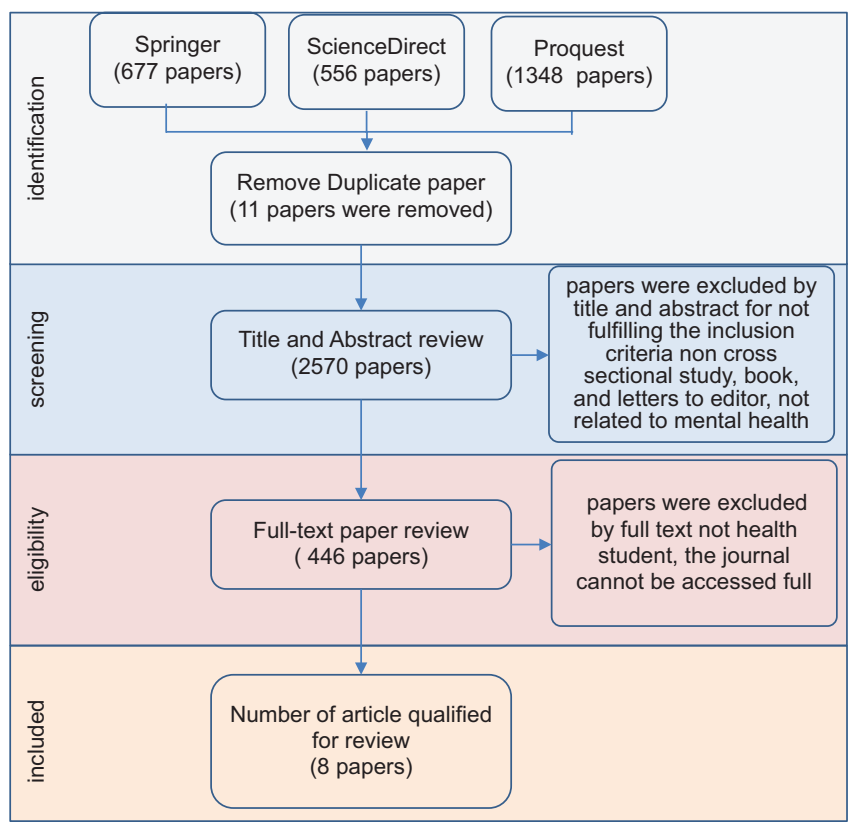

Figure 1: Article search process and other emotional state.

Based on Table 1, the distribution of respondents conducted in Savitsky et al.'s study, respondents were dominated by female than a male with a total of 244 health students as respondents [9]. In a study conducted by Pandey et al., it was found that the distribution of female student respondents was more than male students with a total of 83 respondents [11], from a study conducted in China by Huang L et al., it was found that the number of female respondents was more dominant than that of male, with a total of 430 respondents [5]. While the research in the USA by Coughenour et al found 194 respondents who were dominated by female than male, the same distribution of respondents was also obtained by the study of Eweida et al. in Egypt and Xie et al. in China where female respondents were more than male respondents [8], [12].

From the observations obtained that the anxiety level in health students of $42.8 \%$ is the level of moderate anxiety with the majority occurring in females than males next is severe anxiety with a percentage of $13.1 \%$ dominated also by females as well as mild anxiety. Further results showed that the level of anxiety in healthy students was found to be more in women than men with an average ratio of 5 versus $2(p<0.002)$ [11]. The level of depression shown in Table 1 , health students who experienced a low level of depression was $25.6 \%$ and a severe depression level was $7.3 \%$. In a study by Coughenour et al (2020), it was shown that the policy Stay at Homemade the level of depression in healthy students increased. Higher than before the policy was implemented (average before: 5.58, and after 9.61) [13]. Pandey et al. also found that more depression levels were experienced by female students compared to male students (5 vs. $3, p=0.025$ ) [11]. Not only that, nursing students who were interning at hospitals during the COVID-19 pandemic experienced quite high depression, namely, 62.7\% [11]</AQ10>. While study of Xie et al. in medical student was found that the level of minimal anxiety $13.29 \%$, moderate $1.24 \%$, and severe $0.25 \%$. This study also founded that level of depression with minimal $13.74 \%$, moderate $3.58 \%$, and severe $0.90 \%$ [8]. Study by Dhahri et al. was found that the level of depression in medical and dental students was high, with depressive symptoms felt isolated $63.4 \%$, lack of enjoyment $32.9 \%$, trouble sleeping $41.5 \%$, and hopeless about future $26.2 \%$ [14]. Research by Williams et al. (2021) was found that paramedicine students have level of anxiety with mild $53(35.1 \%)$, moderate 32 (21.19\%), and severe 9 (5.96\%) [15].

In Table 1, the results of the study show Xie et al.'s that health students who spent more than $3 \mathrm{~h}$ focusing on COVID-19 information scored higher on all three subscales than those who focused on COVID-19 for $<3 \mathrm{~h}$. The three subscales are avoidance subscale: $1-3 \mathrm{~h}$ versus $3 \mathrm{~h}: \mathrm{p}=0.024$, intrusion subscale: $11 \mathrm{~h}$ versus $3 \mathrm{~h}$ : pl0.001, 1-3 h versus $3 \mathrm{~h}$ : pl0.001, hyperarousal subscale: $\backslash 1 \mathrm{~h}$ versus $3 \mathrm{~h}$ : $p=0.007,1-3 \mathrm{~h}$ 
Table 1: Systematic review of mental health in health students during COVID-19

\begin{tabular}{|c|c|c|c|c|c|c|c|c|}
\hline \multirow{2}{*}{$\begin{array}{l}\text { Author/ } \\
\text { year }\end{array}$} & \multirow[t]{2}{*}{ Country } & \multirow{2}{*}{$\begin{array}{l}\text { Study } \\
\text { design }\end{array}$} & \multirow{2}{*}{$\begin{array}{l}\text { Population/sample } \\
\text { charasteristic }\end{array}$} & \multirow{2}{*}{$\begin{array}{l}\text { Assesment } \\
\text { tools }\end{array}$} & \multicolumn{4}{|l|}{ Mental health } \\
\hline & & & & & Anxiety & Depression & Stress & Emotional respond, etc \\
\hline $\begin{array}{l}\text { Savitsky } \\
\text { et al. }\end{array}$ & Israel & $\begin{array}{l}\text { Cross } \\
\text { sectional } \\
\text { study }\end{array}$ & $\begin{array}{l}1^{\text {st }} \text { year=65 } \\
\text { (Female: } 89.2 \%, \\
\text { Male: } 10.8 \%) ; 2^{\text {nd }} \\
\text { year }=61(\mathrm{~F}: 86.4 \% \text {, } \\
\mathrm{M}: 13.6 \%), 3^{\text {rd }} \text { year=50 } \\
(\mathrm{F}: 90 \%, \mathrm{M}: 10 \%), 4^{\text {th }} \\
\text { year }=40(\mathrm{~F}: 85 \%, \mathrm{M}: \\
15 \%) \text { Total } 244 \text { students } \\
\text { in the nursing department } \\
\text { in the Ashkelon } \\
\text { Academic College, } \\
\text { Southern District }\end{array}$ & $\begin{array}{l}\text { Anxiety level using } \\
\text { The Generalized } \\
\text { Anxiety } \\
\text { Disorder 7- Item } \\
\text { Scale (GAD-7) } \\
\end{array}$ & $\begin{array}{l}\text { Moderate anxiety } \\
\text { was } 42.8 \% \\
\text { ( } 30.8 \% \text { among } \\
\text { males and } \\
44.7 \% \text { among } \\
\text { the females) and } \\
\text { severe anxiety } \\
\text { was } 13.1 \% 0 \% \\
\text { among males and } \\
14.9 \% \text { among the } \\
\text { females }\end{array}$ & N/A & N/A & $\mathrm{N} / \mathrm{A}$ \\
\hline $\begin{array}{l}\text { Pandey } \\
\text { et al. }\end{array}$ & India & $\begin{array}{l}\text { Cross- } \\
\text { sectional } \\
\text { study }\end{array}$ & $\begin{array}{l}83 \text { of medical } \\
\text { students and junior } \\
\text { doctors of Obstetrics } \\
\text { and Gynaecology } \\
\text { department are } \\
\text { participated, } 47(56.6 \%) \\
\text { were female and } 36 \\
(43.4 \%) \text { were male }\end{array}$ & $\begin{array}{l}\text { Formal anxiety and } \\
\text { depression scores } \\
\text { using the GAD-7 } \\
\text { and PHQ-9 tools }\end{array}$ & $\begin{array}{l}15 / 82(18.3 \%) \\
\text { had anxiety } \\
\text { scores. Females } \\
\text { had significantly } \\
\text { higher median } \\
\text { anxiety }(5 \text { vs. } 2 \text {, } \\
P<0.002) \text { than } \\
\text { male }\end{array}$ & $\begin{array}{l}21 / 82(25.6 \%) \text { had } \\
\text { the lowest possible } \\
\text { depression. } 6 / 82 \\
(7.3 \%) \text { had scores } \\
\text { severe depression. } \\
\text { Females had } \\
\text { higher depression } \\
\text { scores (5 vs. } 3 \text {, } \\
P=0.025) \text { than male } \\
\text { participants }\end{array}$ & $N / A$ & $N / A$ \\
\hline $\begin{array}{l}\text { Huang } \\
\text { et al. }\end{array}$ & China & $\begin{array}{l}\text { comparative } \\
\text { study }\end{array}$ & $\begin{array}{l}\text { The participants' } 602 \\
(74.9 \%) \text { were female, } \\
202(25.1 \%) \text { were male. } \\
374 \text { participants }(46.5 \%) \\
\text { were nurses (mean } \\
23.95 \pm 1.37 \text { years) and } \\
430 \text { participants }(53.5 \%) \\
\text { were nursing students } \\
\text { (mean } 19.00 \pm 0.84 \\
\text { years) }\end{array}$ & $\begin{array}{l}\text { Emotional Respond } \\
\text { the positive and } \\
\text { negative emotion } \\
\text { (PANAS) scale }\end{array}$ & $\begin{array}{l}\text { Mean (SD) Nurse } \\
\text { anxiety: } 3.00 \\
(0.94) ; \text { Nursing } \\
\text { College Student: } \\
2.77(1.14)\end{array}$ & N/A & $\mathrm{N} / \mathrm{A}$ & $\begin{array}{l}\text { Mean (SD) Nurse } \\
\text { (Fear: } 3.16(0.92) ; \\
\text { Sadness: } 2.84(0.90) ; \\
\text { Anger: } 2.20(0.90)) \text {. } \\
\text { Mean (SD) Nursing } \\
\text { College Student (Fear: } \\
2.82(1.15) \text {; Sadness: } \\
2.28(1.14) \text {; Anger: } 1.90 \\
(0.96))\end{array}$ \\
\hline $\begin{array}{l}\text { Coughenour } \\
\text { et al. }\end{array}$ & USA & $\begin{array}{l}\text { Cross- } \\
\text { sectional } \\
\text { study }\end{array}$ & $\begin{array}{l}\text { Total sample 194, Male: } \\
\text { 53 (27.3); Female: } 140 \\
\text { (72.2); Transgender 1: } \\
\text { (0.5). Class standing: } \\
\text { Freshman: } 16 \text { (8.2); } \\
\text { Sophomore: } 26(13.4) ; \\
\text { Junior: } 64 \text { (33.0); } \\
\text { Senior: } 48 \text { (274.7); } \\
\text { Graduated/other: } \\
40 \text { (20.6) }\end{array}$ & $\begin{array}{l}\text { Patient Health } \\
\text { Questionnaire- } \\
\text { PHQ-9 }\end{array}$ & N/A & $\begin{array}{l}63 \% \text { of the } \\
\text { participants had } \\
\text { a worse (higher) } \\
\text { PHQ-9 score after } \\
\text { the stay-at-home } \\
\text { order was issued } \\
\text { compared to before } \\
\text { its issuance. Mean } \\
\text { PHQ-9 score prior to } \\
\text { stay-at-home orders } \\
\text { of } 5.58 \text { compared } \\
\text { to a mean post } \\
\text { order score of } 9.61 \\
(\mathrm{t}=9.14, \mathrm{P}<0.01)\end{array}$ & N/A & N/A \\
\hline $\begin{array}{l}\text { Eweida } \\
\text { et al. }\end{array}$ & Egypt & $\begin{array}{l}\text { Cross- } \\
\text { sectional } \\
\text { descriptive } \\
\text { study }\end{array}$ & $\begin{array}{l}\text { Sample of } 150 \text { intern- } \\
\text { nursing students } \\
\text { from } 13 \text { pediatric } \\
\text { and medical-surgical } \\
\text { units at Alexandria } \\
\text { University Hospitals. } \\
\text { Male: } 47 \text { (31.33), } \\
\text { Female: } 103 \text { (68.67) }\end{array}$ & $\begin{array}{l}\text { General Health } \\
\text { Questionnaire } \\
\text { (GHQ-12), Middle } \\
\text { east respiratory } \\
\text { syndrome COVID- } \\
19 \text { (MERS-CoV) } \\
\text { staff questionnaire }\end{array}$ & $\mathrm{N} / \mathrm{A}$ & $\begin{array}{l}\text { Most of the intern- } \\
\text { nursing students } \\
\text { Depressed } 62.7 \%\end{array}$ & $\begin{array}{l}\text { Intern- nursing students felt } \\
\text { under strain } 77.3 \% \text {. Factor } \\
\text { causing stress: possibility of } \\
\text { getting COVID-19 infection } \\
\text { from patients in the hospital } \\
\text { and transmitting it to the } \\
\text { families ( } 2.89 \pm 0.39 \text { and } \\
2.72 \pm 0.62) \text {; Unavailability } \\
\text { of COVID-19 treatment and } \\
\text { exposure to the situations, } \\
\text { where patients with COVID-19 } \\
\text { died in front of them ( } 2.60 \pm \\
0.67 \text { and } 2.59 \pm 0.68) \text {. Factor } \\
\text { reducing stress: Protective } \\
\text { equipment provided to you } \\
\text { by hospital. Clear and Clear } \\
\text { guidelines from hospital for } \\
\text { infection prevention ( } 2.25 \pm \\
0.81 \text { and } 2.09 \pm 0.81 \text { ) }\end{array}$ & $\begin{array}{l}\text { feel worthless ( } 64.7 \%) \text {, } \\
\text { felt nervous, scared and } \\
\text { angry due to increased } \\
\text { workload during } \\
\text { COVID-19 outbreak } \\
(2.87 \pm 0.34 \text { and } 2.83 \pm \\
0.42 \text { respectively).Not } \\
\text { enjoy their day-to-day } \\
\text { activities ( } 63.3 \%) \text {, } \\
\text { lost their sense of } \\
\text { confidence }(60.0 \%) \text {, } \\
\text { could not overcome } \\
\text { difficulties ( } 56.7 \%) . \\
\text { female students } \\
\text { expressed more } \\
\text { psychological distress } \\
\text { than males (OR=0.17, } \\
95 \% \text { Cl: } 0.057-0.49, \\
P=0.001)\end{array}$ \\
\hline $\begin{array}{l}\text { Xie } \\
\text { et al. }\end{array}$ & China & $\begin{array}{l}\text { Cross- } \\
\text { sectional } \\
\text { study }\end{array}$ & $\begin{array}{l}2705 \text { undergraduate } \\
\text { students were living } \\
\text { outside Hubei, and } \\
\text { none of them was } \\
\text { infected by COVID-19. } \\
\text { Medical student: } 805 \\
(29,75), \text { Non-Medical: } \\
1900(70.24 \%) \text {. Male } \\
608(22.48 \%) \text {, Female: } \\
2097(77.52)\end{array}$ & $\begin{array}{l}\text { The Chinese version } \\
\text { of the Impact of } \\
\text { Event Scale- } \\
\text { Revised (IES-R) } \\
\text {, The Chinese } \\
\text { version of the } \\
\text { 7-item Generalized } \\
\text { Anxiety Disorder } \\
\text { Scale (GAD-7), } \\
\text { the Chinese } \\
\text { version of the } \\
\text { depression module } \\
\text { of the Patient Health } \\
\text { Questionnaire } \\
\text { (PHQ-9) }\end{array}$ & $\begin{array}{l}\text { GAD-7: none } \\
85.21 \% \text {, minimal } \\
13.29 \% \text {, moderate } \\
1.24 \% \text {, severe } \\
0.25 \% \text {; }\end{array}$ & $\begin{array}{l}\text { PQH-9: none } \\
81.79 \% \text {, minimal } \\
13.74 \% \text {, moderate } \\
3.58 \% \text {, severe } \\
0.90 \%)\end{array}$ & $\begin{array}{l}\text { Medical students who spent } \\
\text { more than } 3 \mathrm{~h} \text { focusing } \\
\text { on COVID- } 19 \text { had higher } \\
\text { scores on all three subscales } \\
\text { than those who focused } \\
\text { on COVID-19 for less than } \\
3 \mathrm{~h} \text { (avoidance subscale: } \\
1-3 \mathrm{~h} \text { versus } 3 \mathrm{~h}: \mathrm{P}=0.024 \text {, } \\
\text { intrusion subscale: } 11 \mathrm{~h} \text { versus } \\
3 \mathrm{~h} \text { : pl0.001, } 1-3 \mathrm{~h} \text { versus } \\
3 \mathrm{~h} \text { : pl0.001, hyperarousal } \\
\text { subscale: } 1 \mathrm{~h} \text { hyperarousal } \\
\text { versus } 3 \mathrm{~h}: \mathrm{P}=0.007,1-3 \mathrm{~h} \\
\text { versus } 3 \mathrm{~h}: \mathrm{P}=0.002 \text { ). }\end{array}$ & $\mathrm{N} / \mathrm{A}$ \\
\hline
\end{tabular}


Table 1: (Continued)

\begin{tabular}{|c|c|c|c|c|c|c|c|c|}
\hline \multirow{2}{*}{$\begin{array}{l}\text { Author/ } \\
\text { year }\end{array}$} & \multirow[t]{2}{*}{ Country } & \multirow{2}{*}{$\begin{array}{l}\text { Study } \\
\text { design }\end{array}$} & \multirow{2}{*}{$\begin{array}{l}\text { Population/sample } \\
\text { charasteristic }\end{array}$} & \multirow{2}{*}{$\begin{array}{l}\text { Assesment } \\
\text { tools }\end{array}$} & \multicolumn{4}{|l|}{ Mental health } \\
\hline & & & & & Anxiety & Depression & Stress & Emotional respond, etc \\
\hline $\begin{array}{l}\text { Dhahri } \\
\text { et al. }\end{array}$ & Pakistan & $\begin{array}{l}\text { Cross- } \\
\text { sectional } \\
\text { study }\end{array}$ & $\begin{array}{l}\text { Final year medical } \\
\text { and dental students in } \\
\text { Pakistan } \\
\text { There were a total of } \\
2661 \text { participants who } \\
1753(65.9 \%) \text { female } \\
\text { while } 908(34.1 \%) \text { male }\end{array}$ & $\begin{array}{l}\text { The questionnaire } \\
\text { was developed, } \\
\text { on rating-scales } \\
\text { items, psychological } \\
\text { symptoms } \\
\text { developing } \\
\text { symptoms of } \\
\text { COVID-19 }\end{array}$ & N/A & $\begin{array}{l}\text { Depressive } \\
\text { symptoms: } \\
\text { Felt isolated } 63.4 \% \text {, } \\
\text { lack of enjoyment } \\
32.9 \% \text {, trouble } \\
\text { sleeping } 41.5 \% \text {, } \\
\text { and hopeless about } \\
\text { future } 26.2 \%\end{array}$ & N/A & $\mathrm{N} / \mathrm{A}$ \\
\hline $\begin{array}{l}\text { Williams } \\
\text { et al. }\end{array}$ & Australia & $\begin{array}{l}\text { A convergent } \\
\text { mixed } \\
\text { method } \\
\text { design study }\end{array}$ & $\begin{array}{l}\text { Paramedicine } \\
\text { student with total } 151 \\
\text { respondents, } 74.8 \% \\
\text { female, } 24.8 \% \text { male }\end{array}$ & $\begin{array}{l}\text { 7-item Generalized } \\
\text { Anxiety Disorder } \\
\text { Scale (GAD-7) }\end{array}$ & $\begin{array}{l}\text { Level of anxiety: } \\
\text { Mild: } 53(35.1 \%) \text {, } \\
\text { Moderate: } 32 \\
(21.19 \%), \text { Severe: } \\
9(5.96 \%)\end{array}$ & $\mathrm{N} / \mathrm{A}$ & $\mathrm{N} / \mathrm{A}$ & N/A \\
\hline
\end{tabular}

versus $3 h: p=0.002$ [8]. Other emotional status found in health students, especially nursing, were (Table 1), namely: Feeling afraid with the mean (SD):2.82 (1.15), sadness: 2.28 (1.14), and anger: 1.90 (0.96). Meanwhile, nursing students who were interning at the hospital during the pandemic showed several emotional statuses such as: Feeling worthless (64.7\%), not enjoying daily activities (63.3\%), losing self-confidence $(60.0 \%)$, unable to overcome difficulties (56.7\%). female students expressed more psychological distress than boys $(\mathrm{OR}=0.17,95 \%$ confidence interval $[\mathrm{Cl}]$ : $0.057-0.49, p=0.001)$ [12].

\section{Discussion}

Based on the results of this study, it can be seen that there are several mental health problems experienced by health students during the COVID-19 pandemic. Mental health disorders include anxiety, depression, stress, and other emotional state. Research conducted by Savitsky et al. (2020) shows the percentage of health students who have moderate $(42.8 \%)$ and severe $(13.1 \%)$ anxiety disorders [9]. Studied by Wiliams et al. (2021) also found that paramedicine student has level of mild anxiety 53 $(35.1 \%)$, moderate $32(21.19)$, and severe anxiety 9 (5.96) [15]. During normal conditions or before the COVID-19 pandemic came, even the level of anxiety among health students showed a high enough level [9]. However, with the changing circumstances during the COVD-19 pandemic, it was an added factor that health students experienced anxiety. Thoughts about continuing education in the future and the fear of contracting a virus infection are factors that trigger the level of anxiety among health students during the COVID19 pandemic [9]. Comparing with study of Huang et al. founded that nurse's anxiety more higher then nursing college student [5]. While research conducted by Puci stated that anxiety was very dominant, especially among health workers in Italy, $59.19 \%$ were afraid of being infected with COVID-19; besides that health workers reported sleep disturbances with a percentage of $63.43 \%$ [16]. Nurses who treated patients with a diagnosis of COVID-19 in China also felt the same anxiety. The results showed that the psychological disorders that often occurred in nurses were anxiety $40.8 \%$ (95\% Cl: 34.4-47.2\%) and depression of $26.4 \%$ (95\% Cl: 20.6-42.2\%) [17].

Research by Eweida et al. found that nursing students who are currently interns even experience depression, feel under pressure, and feel useless (62.7\%; 77.3\%, and 64.7\%) [12]. In the study by Dhahri et al. was also found that the level of depression in medical and dental students were high, with depressive symptoms felt isolated $63.4 \%$, lack of enjoyment $32.9 \%$, trouble sleeping $41.5 \%$, and hopeless about future $26.2 \%$ [14]. Xie et al. also found that the students experiencing depression from minimal to severe depression [8]. COVID-19 causes health workers such as nurses and health students to express their experiences related to the uncertainty and fatigue felt, especially nurses who directly deal with COVID-19 patients [18]. In Coughenour's et al. (2020) study, there was a significant reduction in self-reported minutes of physical activity and worse depression scores in survey participants after stay-at-home orders were issued compared to before the policy was enforced [13]. This is because the COVID-19 pandemic comes on suddenly and is unprecedented and is likely to worsen or cause new mental health and stress-related disorders. As a result, there is a need to adapt and/or cope with the major changes that result. The ability of health students to regulate emotions is needed for this adaptation process so that it can reduce the mental health impact that occurs on health students during the pandemic period [13]. In addition, nursing students are preparing to participate in efforts to reduce the incidence of COVID-19 in their countries by starting to implement health protocols in their respective schools [19]

Good emotional regulation is also needed for students who are interning or senior students in the hospital because the level of mental health disorders and emotional states such as feelings of nervousness, fear, and anger are also very high [12]. This is due to several stress factors such as the possibility of catching COVID-19 from patients in the hospital and passing it to their families, unavailability of COVID-19 treatment, 
and exposure to situations where a patient with COVID19 dies in front of them [12]. Emotional status disorders can also occur due to a lack of personal protective equipment, especially health workers who are directly involved in the hospital [20]. Even so, Eweida et al. in his research also explained that there are several factors that can reduce stress, namely: Adequate protective equipment provided by the hospital for students who are interning, clear guidelines, and from the hospital for infection prevention [12]. Others stated that some nurses who carried out tasks in Hubei China conducted by Cui et al. 2020 stated that some of these nurses had good coping mechanisms, strong motivation and good levels of knowledge were important factors to reduce the level of stress that was felt [21].

Xie et al. in their research found that by focusing too much on information about COVID-19 for more than $3 \mathrm{~h}$, health students can have higher levels of anxiety and depression [8]. Therefore, health students should reduce watching, reading, or hearing information related to COVID-19 in the news which can increase their mental and emotional health problems. Except for some information that has a reliable source for selfprotection from the spread of COVID-19 [11]. Mental health disorders that cannot be controlled will lead to a decrease in the quality of life [22]; therefore, the correct source of information will have a psychological impact on someone regarding the current outbreak, this is an important part because of good education related to the COVID outbreak. -19 also contributes to the adaptive response of a person, especially health workers and health students who will become an important part of healthcare workers in the future [23]. Sources of information are a part that can provide positive adherence to both the community and health workers [24]. In addition, online-based information media that can be trusted affect the level of adaptation and reduce the anxiety that can occur to healthy students [25].

\section{Conclusion}

The COVID-19 pandemic has become an epidemic that has greatly shocked the world, not only physical health problems affected by this outbreak but also mental health problems, one of which is anxiety, depression, fear, etc. Things like this can happen in all circles of society but the most at risk of health problems are health workers at the hospital both nurses, doctors, radiologists, and other health workers. Recently, a report that focuses on the health problems of students, especially health students, have become a concern where the results of the study showed that during the pandemic, they felt anxiety, depression, and stress. It is hoped that this review literature research will illustrate the mechanisms that must be taken to solve this problem in the future.

\section{References}

1. Zhang J, Lu X, Jin Y, Zheng Z. Hospitals' responsibility in response to the threat of infectious disease outbreak in the context of the Coronavirus disease-2019 (COVID-19) pandemic: Implications for low-and middle-income countries. Glob Health J. 2020;4(4):113-7. https://doi.org/10.1016/j.glohj.2020.11.005 PMid:33294250

2. World Health Organization. Coronavirus Disease (COVID19); 2020. Available from: https://www.who.int/emergencies/ diseases/novel-coronavirus-2019/question-and-answers-hub/ q-a-detail/coronavirus-disease-covid-19. [Last accessed on 2021 Jan 17]. https://doi.org/10.14293/s2199-1006.1.sor-med. clkmnzy.v1

3. Salari N, Khazaie $\mathrm{H}$, Hosseinian-Far A, Ghasemi $\mathrm{H}$ Mohammadi M, Shohaimi S, et al. The prevalence of sleep disturbances among physicians and nurses facing the COVID-19 patients: A systematic review and meta-analysis. Global Health. 2020;16(1):92. https://doi.org/10.1186/s12992-020-00620-0 PMid:32993696

4. Traunmüller C, Stefitz R, Gaisbachgrabner K, Schwerdtfeger A. Psychological correlates of COVID-19 pandemic in the Austrian population. BMC Public Health. 2020;20(1):1395. https://doi. org/10.1186/s12889-020-09489-5

PMid:32928180

5. Huang L, Lei W, Xu F, Liu H, Yu L. Emotional responses and coping strategies in nurses and nursing students during COVID-19 outbreak: A comparative study. PLoS One. 2020;15(8):e0237303. https://doi.org/10.1371/journal. pone.0237303

PMid:32764825

6. Milgrom $\mathrm{Y}$, Tal $\mathrm{Y}$, Finestone AS. Comparison of hospital worker anxiety in COVID-19 treating and non-treating hospitals in the same city during the COVID-19 pandemic. Isr J Health Policy Res. 2020;9(1):55. https://doi.org/10.1186/s13584-020-00413-1 PMid:33087169

7. Konstantinov V, Berdenova S, Satkangulova G, Reznik A Isralowitz R. COVID-19 impact on Kazakhstan University student fear, mental health, and substance use. Int J Ment Health Addict. 2020;1-7. https://doi.org/10.1007/s11469-020-00412-y PMid:33192199

8. Xie L, Luo H, Li M, Ge W, Xing B, Miao Q. The immediate psychological effects of Coronavirus Disease 2019 on medical and non-medical students in China. Int $\mathrm{J}$ Public Health. 2020;65(8):1445-53. https://doi.org/10.1007/ s00038-020-01475-3

PMid:32910208

9. Savitsky B, Findling Y, Ereli A, Hendel T. Anxiety and coping strategies among nursing students during the COVID-19 pandemic. Nurse Educ Pract. 2020;46:102809. https://doi. org/10.1016/j.nepr.2020.102809

PMid:32679465

10. Wang $Y$, Jing X, Han W, Jing Y, Xu L. Positive and negative affect of university and college students during COVID-19 outbreak: A network-based survey. Int J Public Health. 2020;65(8):1437-43. https://doi.org/10.1007/s00038-020-01483-3

PMid:33063142

11. Pandey U, Corbett G, Mohan S, Reagu S, Kumar S, Farrell T, Lindow S. Anxiety, depression and behavioural changes in junior 
doctors and medical students associated with the coronavirus pandemic: A cross-sectional survey. J Obstet Gynecol India. 2020;71(1):1-5. https://doi.org/10.1007/s13224-020-01366-w PMid:32989348

12. Eweida RS, Rashwan ZI, Desoky GM, Khonji LM. Mental strain and changes in psychological health hub among internnursing students at pediatric and medical-surgical units amid ambience of COVID-19 pandemic: A comprehensive survey. Nurse Educ Pract. 2020;49:102915. https://doi.org/10.1016/j. nepr.2020.102915

PMid:33227694

13. Coughenour C, Gakh M, Pharr JR, Bungum T, Jalene S. Changes in depression and physical activity among college students on a diverse campus after a COVID-19 stay-athome order. J Community Health. 2020;1:1-17. https://doi. org/10.21203/rs.3.rs-70471/v1

14. Dhahri AA, Arain SY, Memon AM, Rao A, Mian MA. The psychological impact of COVID-19 on medical education of final year students in Pakistan: A cross-sectional study. Ann Med Surg (Lond). 2020;60:445-50.

PMid:33251004

15. Williams B, King C, Shannon B, Gosling C. Impact of COVID-19 on paramedicine students: A mixed methods study. Int Emerg Nurs. 2021;56:100996. https://doi.org/10.1016/j. ienj.2021.100996 PMid:33819846

16. Puci MV, Nosari G, Loi F, Puci GV, Montomoli C, Ferraro OE. Risk perception and worries among health care workers in the COVID-19 pandemic: Findings from an Italian survey. Healthcare (Basel). 2020;8(4):535. https://doi.org/10.3390/ healthcare8040535

PMid:33287260

17. Xiong $\mathrm{H}, \mathrm{Yi} \mathrm{S}$, Lin $\mathrm{Y}$. The psychological status and self-efficacy of nurses during COVID-19 outbreak: A cross-sectional survey. Inquiry. 2020;57:46958020957114. https://doi. org/10.1177/0046958020957114 PMid:32900271

18. Arasli H, Furunes T, Jafari K, Saydam MB, Degirmencioglu Z. Hearing the voices of wingless angels: $A$ critical content analysis of nurses' COVID-19 experiences. Int J Environ Res Public Health. 2020;17(22):8484. https://doi.org/10.3390/ ijerph17228484

PMid:33207740
19. Lee RLT, West S, Tang ACY, Cheng HY, Chong CYY, Chien WT, et al. A qualitative exploration of the experiences of school nurses during COVID-19 pandemic as the frontline primary health care professionals. Nurs Outlook [Internet]. 2020:1-10. Available from: http://www.sciencedirect.com/science/article/pii/ S0029655420307107

PMid:33541726

20. Alrubaiee GG, Al-Qalah TA, Al-Aawar MS. Knowledge, attitudes, anxiety, and preventive behaviours towards COVID19 among health care providers in Yemen: An online crosssectional survey. BMC Public Health. 2020;20(1):1541. https:// doi.org/10.21203/rs.3.rs-32387/v5 PMid:33050896

21. Cui $S$, Zhang $L$, Yan $H$, Shi $Q$, Jiang $Y$, Wang $Q$, et al Experiences and psychological adjustments of nurses who voluntarily supported COVID-19 patients in Hubei Province, China. Psychol Res Behav Manag. 2020;13:1135-45. https:// doi.org/10.2147/prbm.s283876 PMid:33312005

22. Sansó N, Galiana L, Oliver A, Tomás-Salvá M, Vidal-Blanco G. Predicting professional quality of life and life satisfaction in Spanish nurses: A cross-sectional study. Int J Environ Res Public Health. 2020;17(12):4366. https://doi.org/10.3390/ ijerph17124366 PMid:32570795

23. de Tantillo L, Christopher R. Implementing the national incident management system at schools of nursing in response to COVID-19. J Prof Nurs. 2021;37(2):255-60. https://doi. org/10.1016/j.profnurs.2020.12.013

PMid:33867077

24. Jiménez-Rodríguez D, García MT, García AS, Del Pino FJ, Ponce-Valencia A, Arrogante O. Nurse training in gender-based violence using simulated nursing video consultations during the COVID-19 pandemic: A qualitative study. Int $\mathrm{J}$ Environ Res Public Health. 2020;17(22):8654. https://doi.org/10.3390/ ijerph17228654

PMid:33233390

25. Jackman D, Konkin J, Yonge O, Myrick F, Cockell J. Crisis and continuity: Rural health care students respond to the COVID19 outbreak. Nurse Educ Pract. 2020;48:102892. https://doi. org/10.1016/j.nepr.2020.10289

PMid:32980557 